\title{
Gambaran Daya Terima Minuman Sari Buah Pedada (Sonneratia sp.) dengan Penambahan Gula Stevia (Stevia rebaudiana)
}

\author{
Description of the Acceptance of Pedada Juice Drink with Additional Stevia Sugar
}

\author{
Dini W. Dari*, Sri Rahmadhani, Dini Junita
}

Program Studi Ilmu Gizi, Sekolah Tinggi Ilmu Kesehatan Baiturrahim, Jl. Prof. M. Yamin, SH No. 30

Kelurahan Lebak Bandung, Kecamatan Jelutung Kota Jambi, Indonesia

*Penulis korespondensi: Dini W. Dari: wulandaridini62@gmail.com

Tanggal submisi: 9 Juli 2021; Tanggal penerimaan: 31 Agustus 2021; Tanggal publikasi: 4 September 2021

\begin{abstract}
One type of coastal plant in the mangrove forest is the pedada (Sonneratia sp.). This fruit has high nutritional value and has the potential to be processed into food products. This fruit is still rarely used because of its sour taste. One form of food processed from pedada fruit is pedada juice drink. The purpose of this study was to describe the acceptance of the parameters of color, aroma, texture, taste, and overall acceptance in the form of selecting the best formulation, which was analyzed using the exponential method of pedada fruit juice drinks. A descriptive analysis within the experimental design was applied in this research. There were 5 samples in this study, namely A1 positive control (200 g, 70\% sucrose sugar), A2 negative control (200 g pedada, 0\% stevia sugar), A3 (200 g pedada, 9\% stevia sugar), A4 (pedada $200 \mathrm{~g}, 18 \%$ stevia sugar), and A5 (200 g pedada, 36\% stevia sugar). The acceptance test used the hedonic method with 40 consumer panelists aged 17-35 years. This research was conducted in May-August 2020. The manufacture of pedada fruit juice drinks and acceptance testing were carried out at home. The results showed that the A4 sample of $200 \mathrm{~g}$ of pedada fruit with the addition of $18 \%$ stevia sugar obtained the highest score on the acceptability of pedada fruit juice drinks and overall acceptance. The average results of each color, aroma, texture, and taste acceptability parameter were 3.9, 3.9, 4.0, and 4.0, respectively.
\end{abstract}

Keywords: Acceptance; fruit juice; pedada; stevia sugar.

(C) The Authors. Publisher Universitas Pattimura. Open access under CC-BY-SA license.

\begin{abstract}
ABSTRAK
Indonesia kaya akan hasil alamnya seperti berbagai jenis hutan yang salah satunya adalah hutan mangrove. Hutan mangrove itu sendiri memiliki berbagai jenis tumbuhan pantai seperti pedada atau Sonneratia sp. Buah ini memiliki nilai gizi yang tinggi dan berpotensi untuk diolah menjadi produk pangan. Buah ini masih jarang digunakan karena rasanya yang asam. Salah satu bentuk pengolahan makanan dari buah pedada adalah minuman sari buah pedada. Adapun tujuan dari penelitian ini yaitu untuk mendeskripsikan penerimaan terhadap parameter warna, aroma, tekstur, dan rasa serta penerimaan secara keseluruhan berupa pemilihan formulasi terbaik yang dianalisis menggunakan metode eksponensial minuman sari buah pedada. Penelitian ini merupakan penelitian eksperimental dengan desain analisis deskriptif murni. Sampel dalam penelitian ini sebanyak 5 sampel yaitu kontrol positif A1 (200 g, gula sukrosa 70\%), kontrol negatif A2 (200 g pedada, gula stevia 0\%), A3 (200 g pedada, gula stevia 9\%), A4 ( pedada 200 g, gula stevia $18 \%$ ), A5 (200 g pedada, gula stevia 36\%). Uji penerimaan menggunakan metode hedonis dengan 40 panelis konsumen berusia 17-35 tahun. Penelitian ini dilakukan pada bulan Mei-Agustus 2020, pembuatan minuman sari buah pedada dan uji daya terima dilakukan di rumah. Akseptabilitas minuman sari buah pedada dan penerimaan keseluruhan yaitu sampel minuman A4 buah pedada $200 \mathrm{~g}$ dengan penambahan gula stevia 18\%, diperoleh skor rata-rata tertinggi $(4,0)$ dengan hasil rata-rata masing-masing parameter akseptabilitas warna 3,9, aroma 3,9, tekstur 4,0, dan rasa 4,0.
\end{abstract}

Kata Kunci: Daya terima; gula stevia; pedada; sari buah.

(C) Penulis. Penerbit Universitas Pattimura. Akses terbuka dengan lisensi CC-BY-SA. 


\section{PENDAHULUAN}

Indonesia adalah sebuah negara yang mempunyai potensi sumber daya alam yang besar dan kaya dengan sumber daya alam hayati maupun sumber daya non hayati. Hal tersebut dibuktikan dengan ditemukannya 3 juta hektar hutan mangrove yang tumbuh di sepanjang pesisir Indonesia. Kabupaten Tanjung Jabung Barat merupakan salah satu wilayah di Provinsi Jambi yang terletak di wilayah Pantai Timur Provinsi Jambi, memiliki garis pantai sepanjang $45 \mathrm{~km}$, dengan sebagian wilayah merupakan kawasan pesisir. Kawasan pesisir Kabupaten Tanjung Jabung Barat memiliki potensi sumber daya hayati dan non hayati yang cukup besar dengan terdapatnya kawasan mangrove. Kebanyakan masyarakat Indonesia belum mengetahui tanaman khususnya buah yang berada di kawasan hutan mangrove yaitu tanaman buah Sonneratia sp. atau yang biasa disebut oleh masyarakat setempat dengan sebutan buah pedada (Meilina, 2019).

Buah pedada ini banyak ditemui di daerah yang perairannya payau. Ciri-ciri buah ini yaitu berebentuk bola, pada bagian bawahnya dibungkus oleh kelopak bunga, sedangkan ujung buahnya bertangkai (Rajis et al., 2017). Buah pedada ini dapat langsung dimakan dan aman karena tidak beracun. Rasa buah pedada yaitu asam sehingga rasa asam yang kuat dan pekat membuat buah ini jarang sekali dimanfaatkan oleh masyarakat sekitar khususnya di pesisir pantai dan hanya dibiarkan berjatuhan dari pohon begitu saja. Buah ini dapat dijadikan sebagai olahan pangan seperti sirup, selai, dan minuman instan (Wiratno et al., 2017). Kandungan zat gizi sangat tinggi yaitu terdapat pada daging buah pedada. Adapun kandungan gizi pada buah ini dengan berat daging buah sebesar $100 \mathrm{~g}$ berupa vitamin $\mathrm{C}$ sebesar $56,74 \mathrm{mg}$, vitamin B2 sebesar 7,65 mg, vitamin B 5,04 mg, dan vitamin A sebesar 221,97 IU (Manalu, 2011). Menurut Ahmed et al. (2010) buah pedada juga mengandung steroid, flavonoid, dan tripenoid yang merupakan komponen fitokimia.

Buah pedada mempunyai nilai gizi yang tinggi sehingga sangat berpotensi untuk diolah menjadi produk pangan. Akan tetapi, informasi pengolahan buah pedada masih sangat terbatas disebabkan karena pengetahuan akan kandungan gizi tersebut masih kurang. Penelitian tentang pengolahan buah pedada menjadi berbagai produk sudah dilakukan juga oleh Dari dan Junita (2020a), Dari et al. (2020b), Dari et al. (2020c), Dari et al.
(2021), Ramadani et al. (2020), Rahmadhani et al. (2021), dan Ramadani et al. (2019).

Salah satu bentuk olahan dari buah pedada adalah minuman sari buah pedada. Sari buah adalah cairan yang dihasilkan dari pemerasan atau penghancuran buah segar yang telah masak (Susanty dan Sampepana, 2017). Dalam pembuatan sari buah bahan utama yang digunakan adalah daging buah, air, dan gula sebagai bahan tambahan. Gula yang dimasukan kedalam produk pangan dapat berfungsi sebagai pembentuk tekstur dan pembentuk flavor atau rasa melalui reaksi pencoklatan (Fitri et al., 2017). Biasanya jenis gula yang digunakan dalam pembuatan sari buah adalah gula pasir dikarenakan gula pasir berfungsi untuk memberikan rasa manis dan dapat meningkatkan citarasa (Sumantri, 2018). Namun penggunaan gula pasir yang berlebihan dapat menimbulkan efek bagi kesehatan tubuh seperti diabetes melitus dan kegemukan (Raini dan Isnawati, 2011).

Penderita diabetes melitus dan obesitas sangat membutuhkan pemanis sebagai pengganti gula, sehingga diperlukan modifikasi minuman dengan bahan yang diperbolehkan untuk penderita diabetes melitus seperti gula stevia sebagai alternatif untuk mengganti gula pasir dalam suatu produk minuman. Gula stevia merupakan salah satu pemanis rendah kalori (low calorie sweeteners) dan termasuk ke dalam kategori pemanis alami. Pemanis rendah kalori seperti gula stevia aman dikonsumsi untuk kalangan anak-anak usia di atas 6 tahun, dewasa, sampai lansia yang berusia lebih dari 55 tahun (Sylvetsky dan Rother, 2016).

Gula stevia berasal dari ekstrak daun stevia (Stevia rebaudiana) yang merupakan salah satu bahan pemanis alami rendah kalori yang berasal dari tumbuhan. Rasa manis yang ditimbulkan berasal dari glikosida dalam bentuk steviosida. Tingkat kemanisan pada gula stevia yaitu sebesar 200-300 kali kemanisan dari gula tebu atau gula sukrosa, gula stevia ini berkalori rendah, tidak mengganggu rasa pada minuman sirup, tidak berbahaya atau bersifat non karsinogenik (Ratnani dan Anggraeni, 2005).

Berdasarkan perlakuan terbaik pada penelitian yang dilakukan oleh Dari dan Junita (2020a) yaitu berat buah pedada sebesar $200 \mathrm{~g}$ dan penambahan gula sukrosa sebanyak $70 \%$ maka dalam penelitian ini, perlakuan yang digunakan yaitu perlakuan penambahan buah pedada masingmasing perlakuan $200 \mathrm{~g}$ serta penambahan gula sukrosa $70 \%$, tanpa gula stevia $0 \%$ dan juga tanpa 
gula sukrosa (bebas gula), gula stevia 9\%, 18\%, dan $36 \%$. Tujuan dari penelitian ini adalah untuk mengetahui pengaruh penambahan gula stevia terhadap gambaran daya terima pada minuman sari buah pedada.

\section{METODE PENELITIAN}

\section{Waktu dan Tempat Penelitian}

Penelitian ini dilaksanakan pada bulan Mei sampai dengan Agustus 2020. Penelitian minuman sari buah pedada ini dilakukan di rumah dan telah melakukan upaya mencegah resiko terjadinya kontaminasi pangan dengan memastikan bahwa kondisi penjamah makanan dalam keadaan bersih, mencuci tangan dan menggunakan sarung tangan sebelum memegang bahan makanan dan alat, mencuci bahan dengan air mengalir, serta memastikan alat-alat dan dapur dalam keadaan bersih.

Pengujian daya terima dilakukan di rumah masing-masing panelis guna menerapkan work from home untuk meningkatkam kewaspadaan terhadap penyebaran virus Covid-19 yang tidak memungkinkan pekerjaan ini dilakukan di laboratorium. Prosedur dalam pencarian panelis yaitu dengan cara broadcast pesan via aplikasi whatsapp. Uji daya terima menggunakan alat kuesioner uji organoleptik dan dilakukan dengan syarat social distancing (berjarak) serta menerapkan protokol kesehatan.

\section{Bahan}

Bahan yang digunakan dalam pembuatan minuman sari buah pedada adalah buah pedada yang telah matang dengan diameter sekitar 6-8 $\mathrm{cm}$, berbentuk bulat, dan agak sedikit lembut yang diperoleh dari Kabupaten Tanjung Jabung Barat, gula stevia (Tropicana Slim, Indonesia) dan gula sukrosa (Gulaku, Indonesia).

\section{Tahapan Penelitian}

\section{Pembuatan Sari Buah Pedada dengan Gula Stevia dan Gula Sukrosa}

Proses pembuatan sari buah pedada dengan penambahan gula stevia mengacu pada Ramadani et al. (2019). Pembuatan diawali dengan buah pedada disortir dan dipilih buah yang telah matang dan tidak busuk. Buah pedada dipotong kecil-kecil menggunakan pisau, kelopak dan kulitnya dibuang, selanjutnya daging buah pedada ditimbang dan dicuci bersih lalu di-blender dengan menambahkan air yang perbandingannya 1:10 (buah pedada dalam g: air dalam $\mathrm{mL}$ ). Sari buah disaring menggunakan saringan kain. Sari buah pedada dipanaskan pada suhu $80^{\circ} \mathrm{C}$ dengan waktu kurang lebih 20 menit, sambil diaduk. Selanjutnya angkat sari buah pedada dan disaring kembali, dan tambahkan gula stevia (Tropicana Slim) berdasarkan berat buah sesuai dengan perlakuan yang telah ditetapkan. Pembuatan sari buah dengan gula sukrosa (Gulaku, Indonesia) mengikuti prosedur yang sama, hanya saja gula sukrosa dimasukkan pada saat proses pemasakan sebanyak 70\% (140 g) sambil diaduk.

Penambahan gula stevia dan gula sukrosa pada proses pembuatan minuman sari buah pedada berbeda. Penambahan gula sukrosa dimasukan pada saat proses pemasakan sedangkan gula stevia dimasukan setelah proses pemasakan hal ini dikarenakan mengikuti saran penyajian pada produk gula stevia yang menganjurkan gula dilarutkan pada minuman yang telah jadi.

\section{Metode Analisis}

Metode analisis parameter sensoris yang digunakan pada penelitian ini berupa uji organoleptik atau yang biasa disebut juga dengan uji kesukaan atau penerimaan (preference or hedonic test). Uji penerimaan yang digunakan berupa uji hedonik yaitu uji kesukaan berupa pernyataan suka atau tidak suka terhadap suatu produk. Pengujian dilakukan oleh 40 orang panelis yaitu panelis konsumen yang diperoleh dari masyarakat Kota Jambi dengan rentang usia 17-35 tahun.

Panelis dalam penelitian ini memiliki kriteria inklusi. Adapun kriteria inklusi untuk panelis masyarakat Kota Jambi yang menjadi panelis adalah memiliki rentang usia 17-35 tahun. Berjenis kelamin laki-laki maupun perempuan, telah bersedia menjadi panelis, sehat jasmani rohani, dan dapat berkomunikasi dengan baik. Pengujian daya terima ini dilakukan dengan cara menyiapkan sampel secara acak setelah diberi kode sesuai dengan rancangan percobaan. Sampel minuman sari buah pedada dengan penambahan gula dan tanpa penambahan gula (0\% stevia) sebanyak $15 \mathrm{~mL}$ diletakkan di dalam wadah kemudian disajikan dihadapan panelis.

Panelis diberikan arahan bagaimana tata 
cara penilaian, kemudian panelis diminta mencicipi sampel dan memberikan panilaian dengan cara mengisi lembar pernyataan yang tersedia. Penilaian dimulai dari skor 1: sangat tidak suka, skor 2: tidak suka, skor 3: agak suka, skor 4: suka, dan skor 5: sangat suka.

\section{Rancangan Percobaan}

Penelitan ini merupakan penelitian eksperimen dengan analisis deskriptif murni untuk uji daya terima hedonik dengan parameter warna, aroma, tekstur, rasa serta pemerimaan secara keseluruhan (overall) yang dianalisis menggunakan metode perbandingan eksponensial yang mengacu pada penelitian Junita et al. (2017). Pada penelitian ini terdapat dua kontrol yaitu kontrol positif dan kontrol negatif. Kontrol positif yaitu minuman sari buah pedada dengan penambahan gula sukrosa. Kontrol negatif yaitu minuman sari buah pedada tanpa penambahan gula stevia.

Penelitian ini terdapat lima taraf perlakuan yaitu: penambahan gula sukrosa $70 \%$ (kontrol positif) (A1), penambahan gula stevia $0 \%$ (kontrol negatif) (A2), penambahan gula stevia 9\% (A3), penambahan gula stevia $18 \%$ (A4), penambahan gula stevia $36 \%$ (A5).

\section{HASIL DAN PEMBAHASAN}

Analisis daya terima dilakukan untuk memperoleh data daya terima dari produk minuman sari buah pedada yang telah dibuat dan bertujuan untuk mengetahui gambaran tingkat kesukaan panelis dan formulasi terbaik sampel secara keseluruhan (overall) terhadap minuman sari buah pedada. Tabel 1 menunjukkan hasil daya terima minuman sari buah pedada dengan penambahan gula stevia. Hasil penelitian ini menunjukkan bahwa minuman buah pedada pada sampel A4 memperoleh nilai rata-rata tertinggi pada setiap parameter yaitu warna, aroma, tekstur, rasa serta penerimaan secara keseluruhan.

Uji daya terima merupakan pengujian dengan menggunakan indera manusia sebagai alat utama untuk mengukur daya terima pada suatu produk dan biasanya juga disebut dengan uji organoleptik (Wahyuningtias, 2010). Hasil analisis daya terima minuman sari buah pedada dengan penambahan gula stevia dapat dilihat pada Tabel 1 .

\section{Warna}

Warna merupakan parameter yang cukup penting ketika sedang ingin menentukan kualitas produk pangan. Warna merupakan salah satu parameter uji sensoris dan merupakan tampilan yang dapat dinilai dan dianalisis oleh panelis (Amriani et al., 2019). Parameter warna ini merupakan parameter yang dapat diamati langsung oleh indra penglihatan. Oleh sebab itu indikator warna merupakan parameter uji yang penting.

Pada Tabel 1 menunjukkan bahwa rata-rata nilai hedonik atau tingkat kesukaan dari parameter warna berkisar dari rentang 3,5 hingga 4 yang masuk ke dalam kategori agak suka dan suka. Formulasi tertinggi diperoleh dari perlakuan A1 sebagai kontrol positif yaitu sebesar 4 dengan penambahan gula sukrosa $70 \%$ dan untuk formulasi terendah yaitu diperoleh dari perlakuan A2 sebagai kontrol negatif sebesar 3,5 tanpa penambahan gula stevia.

Tabel 1. Hasil uji daya terima minuman sari buah pedada

\begin{tabular}{cccccc}
\hline Perlakuan & Warna & Aroma & Tekstur & Rasa & Overall \\
\hline A1 & $4,0 \pm 0,00$ & $3,8 \pm 0,63$ & $3,8 \pm 0,43$ & $3,7 \pm 0,47$ & $3,8 \pm 0,12$ \\
A2 & $3,5 \pm 0,78$ & $3,5 \pm 0,84$ & $3,7 \pm 0,66$ & $3,2 \pm 0,84$ & $3,5 \pm 0,20$ \\
A3 & $3,7 \pm 0,76$ & $3,7 \pm 0,73$ & $3,7 \pm 0,62$ & $3,5 \pm 0,64$ & $3,7 \pm 0,10$ \\
A4 & $3,9 \pm 0,57$ & $3,9 \pm 0,57$ & $4,0 \pm 0,68$ & $4,0 \pm 0,56$ & $4,0 \pm 0,05$ \\
A5 & $3,6 \pm 0,77$ & $3,7 \pm 0,76$ & $3,5 \pm 0,67$ & $3,5 \pm 0,67$ & $3,6 \pm 0,09$ \\
\hline
\end{tabular}

Keterangan: A1 = Sari buah pedada dengan penambahan gula sukrosa 70\% (kontrol positif); A2 = Sari buah padada tanpa penambahan gula stevia 0\% (kontrol negatif); A3 = Sari buah pedada dengan penambahan gula stevia 9\%; A4 = Sari buah pedada dengan penambahan gula stevia 18\%; A5 = Sari buah pedada dengan penambahan gula stevia $36 \%$. Skor nilai uji daya terima $1=$ sangat tidak suka, $2=$ tidak suka, $3=$ agak suka, $4=$ suka, $5=$ sangat suka. 
Berdasarkan keterangan yang disampaikan oleh panelis, beberapa responden lebih menyukai warna minuman sari buah pedada A1 dengan penambahan gula sukrosa 70\% (kontrol positif) dibandingkan dengan perlakuan A2 tanpa gula stevia, A3 9\%, A4 18\%, A5 36\% dengan penambahan gula stevia. Hal ini disebabkan karena adanya perbedaan jenis gula pada saat proses pembuatan minuman sari buah pedada yaitu gula sukrosa dan gula stevia. Minuman sari buah pedada dengan penambahan gula sukrosa $70 \%$ dibuat dengan cara gula sukrosa dimasukkan pada saat proses pemasakan atau pemasakan sedang berlangsung, sehingga terjadi perubahan warna yaitu menjadi kuning keruh hingga jingga atau oranye.

Perubahan warna pada minuman dengan penambahan gula sukrosa disebabkan oleh reaksi antara sukrosa dengan komponen dalam buah. Pendapat ini sejalan dengan penelitian yang dilakukan oleh Fitri et al. (2017) yang menyatakan bahwa minuman sari buah belimbing yang dipanaskan dengan penambahan gula sukrosa menghasilkan warna kuning kecoklatan yang disebabkan karena warna yang dihasilkan dari buah itu sendiri dan disebabkan karna banyaknya gula yang ditambahkan pada minuman tersebut. Suatu produk pangan mengalami perubahan warna menjadi gelap disebabkan oleh reaksi pencoklatan non enzimatis. Proses tersebut merupakan proses pemecahan molekul sukrosa menjadi molekul glukosa dan fruktosa yang menyebabkan terjadinya reaksi polimerisasi yaitu terbentuknya komponen polimer berwarna sehingga larutan menjadi berwarna gelap (Ramadani et al., 2020). Hal ini juga sesuai dengan pendapat Desrosier (2008) bahwa perubahan warna yang terjadi karena adanya proses degradasi gula tanpa asam amino atau yang disebut juga dengan reaksi pencoklatan non enzimatis apabila gula dipanaskan di atas titik cairnya dan selama proses pemasakan kerusakan utama dalam buah-buahan terjadi pada karbohidrat.

Terdapat perbedaan yaitu pada minuman sari buah pedada dengan penambahan gula stevia tidak terjadi perubahan warna. Warna yang dihasilkan adalah putih jernih hal ini disebabkan karena gula stevia tidak dimasukan pada saat proses pemasakan melainkan ditambahkan pada saat minuman sari buah pedada telah selesai dimasak sehingga tidak terjadi proses karamelisasi atau reaksi pencoklatan. Menurut pendapat Amalia (2016) sifat dari gula sukrosa berbeda dengan gula stevia yaitu gula sukrosa seperti gula tebu biasa apabila dipanaskan melebihi titik leburnya $160^{\circ} \mathrm{C}$ maka akan terjadi reaksi pencoklatan non enzimatis yaitu karamelisasi sedangkan gula stevia tahan terhadap pemanasan pada suhu $200^{\circ} \mathrm{C}$ dan tidak banyak mengandung sukrosa. Hal lain yang menyebabkan warna jernih pada minuman sari buah pedada ini karena penggunaan gula stevia pada penelitian ini tidak terlalu banyak. Berdasarkan penelitian yang dilakukan Ghazi et al. (2013) suatu larutan yang diekstraksi atau dimasak menggunakan gula stevia akan memberikan warna coklat akibat tanin yang terkandung pada gula stevia. Dari nilai rata-rata minuman sari buah pedada pada perlakuan A2, A3, A4, dan A5 memperoleh rentang nilai antara 3,5 sampai 3,9 yang masuk ke dalam kategori agak suka. Berdasarkan hasil uji daya terima komentar yang disampaikan oleh panelis melaporkan bahwa warna minuman sari buah dengan penambahan gula stevia lebih jernih daripada warna minuman sari buah dengan penambahan gula sukrosa. Warna jernih ini disebabkam karena gula stevia tidak dimasak secara bersamaan. Berdasarkan penelitian Meilina (2019) tentang analisis warna pada minuman sari buah pedada menggunakan alat chromameter menyatakan bahwa sampel minuman dengan penambahan gula lebih cerah dibandingkan minuman tanpa penambahan gula dengan hasil nilai $\mathrm{L}^{*}$ (Lightness) tingkat kecerahan berkisar 45,01-49,16.

Dalam penelitian ini, minuman sari buah pedada dengan penambahan gula stevia memiliki warna yang hampir sama dengan minuman sari buah pedada tanpa penambahan gula stevia yaitu jernih yang semulanya minuman tersebut keruh. Menurut penelitian yang dilakukan oleh Balaswamy et al. (2014) tentang minuman buah dengan pemanis alami melaporkan bahwa terjadi perubahan warna minuman buah menjadi jernih dikarenakan adanya kandungan steviosida di dalam gula stevia. Gula dapat memberi warna pada produk pangan dengan reaksi maillard dan karamelisasi. Reaksi ini terjadi antara gula dan asam amino yang akan menyebabkan timbulnya warna kecoklatan. Karamelisasi terjadi ketika karbohidrat terpapar suhu tinggi. Reaksi karamelisasi dan maillard ini sering terjadi pada saat proses pembuatan sirup, minuman ringan, ataupun produk pangan minuman yang lainnya (Zaitoun et al., 2018). 


\section{Aroma}

Aroma memiliki peran penting dalam suatu produk pangan. Aroma merupakan suatu zat atau komponen tertentu yang mempunyai beberapa fungsi dalam produk pangan, seperti memperbaiki, membuat lebih bernilai atau dapat diterima sehingga peranan aroma mampu menarik kesukaan konsumen terhadap produk pangan tersebut (Amriani et al., 2019).

Pada Tabel 1 menunjukkan bahwa rata-rata nilai hedonik atau tingkat kesukaan dari minuman sari buah pedada untuk parameter aroma berkisar dari rentang 3,5 hingga 3,9 yang masuk ke dalam kategori agak suka. Formulasi tertinggi diperoleh dari perlakuan A4 dengan penambahan gula stevia $18 \%$ yaitu sebesar 3,9 dan untuk formulasi terendah yaitu diperoleh dari perlakuan A2 sebagai kontrol negatif sebesar 3,5 tanpa penambahan gula stevia.

Komentar panelis berdasarkan hasil penilaian seluruh sampel minuman sari buah pedada, bahwa mereka agak suka dengan aroma minuman sari buah pedada tersebut. Berdasarkan penilaian panelis, minuman sari buah pedada perlakuan A1 dengan penambahan gula sukrosa $70 \%$ sebagai kontrol positif, perlakuan A2 (tanpa penambahan gula stevia), A3, A4, dan A5 dengan penambahan gula stevia sama saja, tidak ada perbedaan aroma yang terlalu jauh karena memiliki aroma khas daging buah pedada yang masam. Aroma yang khas dapat dirasakan oleh indera penciuman tergantung dari bahan yang ditambahkan pada makanan atau minuman tersebut. Aroma dalam suatu produk biasanya akan berkurang karena dipengaruhi oleh bahan yang digunakan dan juga bisa terjadi selama penanganan, pengolahan serta penyimpanan (Amriani et al., 2019). Hasil analisis daya terima parameter aroma melaporkan bahwa aroma minuman sari buah pedada sampel A4 (penambahan gula stevia 18\%) adalah sampel yang lebih banyak disukai. Minuman sari buah pedada dengan penambahan gula lebih banyak disukai oleh panelis dibandingkan yang dengan tanpa penambahan gula yaitu sampel kontrol negatif A2 (gula stevia 0\%).

Panelis menilai aroma antara minuman yang diberikan gula sukrosa dan diberikan gula stevia tidak ada perbedaan. Panelis mengatakan aroma semua minuman seperti aroma khas buah pedada. Berdasarkan penelitian yang dilakukan oleh Amalia (2016) konsentrasi penambahan gula stevia tidak berpengaruh terhadap aroma minum- an. Hal ini disebabkan karena penggunaan gula stevia pada minuman tidak terlalu banyak dan juga gula stevia tidak mempunyai aroma yang khas seperti gula aren ataupun jenis gula yang lainnya.

Hasil penelitian Rocha dan Bolini (2015) menunjukkan bahwa tidak ditemukan perbedaan aroma pada minuman sari buah dengan penambahan gula sukrosa ataupun gula stevia yang memperoleh nilai tidak jauh berbeda yaitu 3,84\% untuk minuman dengan penambahan gula sukrosa dan $3,78 \%$ untuk minuman dengan penambahan gula stevia sehingga penambahan gula tidak terlalu berpengaruh terhadap aroma minuman.

Produk minuman sari buah pedada dengan penambahan gula sukrosa menurut penelitian yang dilakukan oleh Sumantri (2018), bahwa aroma buah pedada yang masam apabila bercampur gula yang dimasak dan dengan konsentrasi gula yang tinggi akan mempengaruhi aroma minuman yang dihasilkan sehingga perpaduan aroma ini kurang disukai panelis. Aroma merupakan salah satu faktor yang dapat menentukan makanan dan minuman dapat diterima konsumen dan juga merupakan parameter dalam menentukan kualitas produk minuman ataupun makanan (Rahman et al., 2016).

\section{Tekstur}

Tekstur merupakan suatu penginderaan yang meliputi kebasahan, kering, keras, halus, kasar, dan berminyak. Tekstur dalam bahan pangan sangat ditentukan oleh zat-zat yang terkandung dalam bahan pangan seperti air, lemak, protein, dan karbohidrat (Novriyanti dan Muhammad, 2016). Pada Tabel 1 menunjukkan bahwa rata-rata nilai hedonik atau tingkat kesukaan dari minuman sari buah pedada untuk parameter aroma berkisar dari rentang 3,5 hingga 4,2 yang masuk ke dalam kategori agak suka dan suka. Formulasi tertinggi diperoleh dari perlakuan A4 dengan penambahan gula stevia $18 \%$ yaitu sebesar 4,2 dan untuk formulasi terendah yaitu diperoleh dari perlakuan A5 sebesar 3,5 dengan penambahan gula stevia $36 \%$.

Berdasarkan penilaian dari panelis tidak terdapat perbedaan tekstur antara minuman sari buah pedada dengan penambahan gula sukrosa dan penambahan gula stevia. Panelis menyatakan bahwa tekstur minuman sari buah pedada memiliki tekstur yang rata-rata keseluruhan sampel sama yaitu cair seperti air mineral tidak kental seperti tekstur sirup atau madu. Panelis lebih 
menyukai sampel A4 formulasi dengan penambahan gula stevia $18 \%$. Berdasarkan penelitian yang dilakukan Meilina (2019) penambahan gula tidak menunjukkan pengaruh yang nyata terhadap tekstur sari buah dikarenakan sari buah dibuat dengan air dan dipanaskan. Semakin sedikit air dan semakin banyak gula yang ditambahkan maka pektin buah akan lebih mudah berinteraksi dengan gula dan dari penggabungngan keduanya akan dapat membentuk tekstur yang lebih kental. Tujuan pemberian gula pada bahan pangan adalah untuk meningkatkan kekentalan produk pangan olahan sehingga pektin pada buah berfungsi sebagai pengental dan pembentuk tekstur.

Tekstur cair minuman sari buah pedada dalam penelitian ini disebabkan karena gula stevia yang ditambahkan pada produk minuman sari buah pedada hanya sedikit dan disebabkan juga karena tidak ada penambahan gula stevia pada saat proses pemasakan atau pemanasan melainkan gula stevia dimasukkan pada saat sari buah telah dimasak sehingga tidak terjadi proses pengentalan yang disebabkan karena penambahan gula. Menurut Rajis et al. (2017) kekentalan suatu zat cair dengan penambahan gula tergantung pada banyaknya gula yang ditambahkan dan lama waktu pemanasan, semakin banyak gula yang ditambahkan dan semakin lama pemanasan dilakukan minuman yang dihasilkan akan semakin kental.

Zaitoun et al. (2018) menyatakan bahwa gula dapat merubah tekstur suatu produk pangan karena gula dalam keadaan kristal memiliki kemampuan berinteraksi dengan air dan dapat membentuk tekstur minuman. Molekulnya dapat berubah-ubah tergantung pada proses pengolahan. Apabila gula ditambahkan dalam jumlah yang banyak ke dalam suatu larutan maka gula akan mengikat molekul air dan terjadinya penurunan aktivitas air sehingga menyebabkan larutan menjadi kental dan memiliki tingkat viskositas (kekentalan).

Dalam penelitian ini tekstur minuman sari buah secara keseluruhan adalah cair. Hal ini sejalan dengan hasil penelitian Meilina (2019) tentang karakteristik minuman fungsional sari buah pedada yang melaporkan bahwa tekstur minuman sari buah pedada secara keseluruhan tidak banyak menunjukkan perbedaan disetiap perlakuan, hanya saja mengalami peningkatan dengan semakin besarnya konsentrasi gula yang ditambahkan dan viskositas (tingkat kekentalan) pada minuman sari buah ini tidak terlalu tinggi atau tidak terlalu kental seperti minuman pada umumnya disebabkan karena penambahan konsentrasi gula yang tidak banyak dan konsentrasi air yang cukup tinggi jika dibandingkan dengan proporsi buah.

\section{Rasa}

Rasa merupakan parameter yang terdiri dari empat jenis rasa dasar yaitu asin, asam, manis, dan pahit. Rasa juga merupakan salah satu faktor penting dalam menentukan keputusan dari penilaian bagi konsumen untuk dapat menerima atau tidak menerima suatu produk pangan meskipun dari paramter warna, aroma, tekstur bernilai baik jika rasa tidak disukai atau tidak enak maka produk akan ditolak (Novriyanti et al., 2016).

Pada Tabel 1 menunjukkan bahwa rata-rata nilai hedonik atau tingkat kesukaan dari minuman sari buah pedada untuk parameter rasa berkisar dari rentang 3,2 hingga 4,0 yang masuk ke dalam kategori agak suka dan suka. Formulasi tertinggi diperoleh dari perlakuan A4 dengan penambahan gula stevia $18 \%$ yaitu sebesar 4,0 dan untuk formulasi terendah yaitu diperoleh dari perlakuan A2 sebagai kontrol negatif sebesar 3,2 tanpa penambahan gula stevia.

Umumnya bahan pangan atau produk pangan tidak hanya terdiri dari satu rasa, tetapi merupakan gabungan dari berbagai macam rasa secara terpadu sehingga menimbulkan cita rasa yang utuh (Winarno, 2004). Penilaian terhadap rasa minuman sari buah pedada lebih bersifat relatif untuk masing-masing panelis. Panelis tidak menyukai rasa minuman pada pada perlakuan kontrol negatif A2 tanpa penambahan gula stevia. Panelis lebih menyukai rasa dari perlakuan A4 dengan penambahan gula stevia $18 \%$.

Jika dibandingkan antara rasa minuman sari buah pedada A1 dengan penambahan gula sukrosa $70 \%$ dan minuman sari buah pedada A4 dengan penambahan gula stevia $18 \%$ panelis lebih menyukai rasa dari minuman sari buah pedada dengan penambahan gula stevia $18 \%$, dengan alasan bahwa minuman sari buah pedada dengan penambahan gula stevia sebanyak $18 \%$ lebih manis dibandingkan dengan minuman sari buah pedada dengan penambahan gula sukrosa $70 \%$. Hal ini sesuai dengan pernyataan Tahir et al. (2017) bahwa semakin banyak penambahan pemanis stevia maka rasa pada minuman akan semakin manis dikarenakan kandungan steviosida 
pada gula stevia yang memberikan rasa manis 250 kali lipat dibandingkan dengan gula sukrosa.

Rasa manis pada gula stevia disebabkan karena gula stevia mengandung 3 jenis glikosida yaitu steviosida yang memiliki rasa manis, rebaudisida dan dulkosida yang ketiganya terikat pada karbohidrat seperti rhamnosa, fruktosa, glukosa, silosa, arabinosa (Rukmana, 2003). Berdasarkan komentar, panelis mengungkapkan bahwa dari keempat formulasi penambahan gula stevia pada minuman sari buah pedada, yang lebih mendekati dengan rasa manisnya dengan perlakuan A1 70\% gula sukrosa (kontrol positif) adalah minuman sari buah pedada perlakuan A4 dengan penambahan gula stevia $18 \%$. Panelis beranggapan bahwa rasa manis pada perlakuan A4 sedikit lebih manis dari pada minuman A1 dengan penambahan $70 \%$ gula sukrosa tersebut sehingga rasa manisnnya tidak terlalu berbeda jauh dibandingkan dengan rasa manis pada perlakuan A5 dengan penambahan gula stevia sebanyak $36 \%$ yang menurut panelis rasa manis pada perlakuan A5 ini menimbulkan rasa manis yang terlalu pekat. Sedangkan komentar panelis pada minuman sari buah pedada perlakuan A2 kontrol negatif $0 \%$ tanpa penambahan gula stevia dan A3 dengan penambahan gula stevia sebanyak 9\% rasa minuman tersebut masih terasa asam khas buah pedada dan sedikit asam kombinasi manis. Menurut penelitian yang dilakukan oleh Widad et al. (2018) menyatakan bahwa rasa asam kombinasi manis pada produk minuman sari buah disebabkan karena adanya penambahan konsentrasi gula stevia yang mempunyai tingkat kemanisan lebih tinggi dibandingkan dengan gula sukrosa. Rasa yang ditimbulkan pada suatu produk minuman dapat dipengaruhi oleh interaksi antara komponen pemanis alami dari buah dan juga dari pemanis tambahan. Minuman tanpa gula sukrosa yang diganti dengan konsentrasi gula stevia tinggi akan menimbulkan sensasi rasa manis yang dipengaruhi oleh faktor-faktor seperti banyaknya stevia yang digunakan, suhu, metode pengolahan, dan banyaknya media pendispersi atau zat pelarut pada minuman (Alizadeh et al., 2014).

Berdasarkan penelitian Meilina (2019) menyatakan bahwa minuman sari buah pedada dengan penambahan buah pedada tanpa penambahan gula akan terasa sangat asam karena rasa buah pedada itu sendiri sangat asam sementara minuman sari buah pedada dengan penambahan gula yang tinggi lebih banyak disukai oleh panelis karena menghasilkan rasa manis keasaman.
Panelis lebih memilih perlakuan A4 dengan penambahan gula stevia $18 \%$ yang hampir mendekati rasa pada perlakuan kontrol positif A1 dengan penambahan gula sukrosa sebanyak $70 \%$. Rasa merupakan faktor terpenting yang berhubungan dengan pengujian organoleptik. Rasa terdiri dari komponen-komponen yang terdapat pada saat pembuatan dan dapat pula terdiri dari komponen yang terdapat dalam bahan baku atau dari bahan yang sengaja ditambahkan dalam upaya meningkatkan kualitas dari produk pangan atau (Asmawati et al., 2018). Gula memegang peranan penting dalam menentukan parameter rasa, karena peran gula selain memberikan rasa manis juga dapat menyempurnakan rasa asam pada minuman (Meilina, 2019).

Dalam hasil penelitian lain tentang uji sensorik stevioside sebagai pengganti sukrosa dalam jus buah persik yang dilakukan oleh Parpinello et al. (2001) melaporkan bahwa penambahan gula stevia sebanyak $160 \mathrm{mg} / \mathrm{L}$ berhasil sepenuhnya menggantikan rasa manis dibandingkan dengan penambahan gula sukrosa sebanyak $34 \mathrm{~g} / \mathrm{L}$ dalam produk jus buah persik sehingga dapat disimpulkan bahwa penambahan gula stevia dapat mempengaruhi karaktersitik sensorik produk pangan. Hal tersebut sejalan dengan penelitian ini, rasa manis yang ditimbulkan dengan penambahan gula stevia $18 \%$ pada minuman sari buah perlakuan sampel A4 setara dengan minuman sari buah dengan penambahan gula sukrosa $70 \%$ hal ini disebabkan karena gula stevia mempunyai tingkat kemanisan 200-300 kali lebih tinggi dibandingkan gula sukrosa.

\section{Overall}

Penilaian formulasi terbaik (overall) pada uji daya terima yang dilakukan oleh panelis merupakan penilaian secara menyeluruh dari sampel minuman sari buah pedada terhadap parameter warna, aroma, tekstur, dan rasa. Tingkat penilaian panelis untuk formulasi terbaik dari keseluruhan sampel minuman sari buah pedada berdasarkan Tabel 1 menunjukkan bahwa sampel A4 perlakuan buah pedada $200 \mathrm{~g}$ dengan penambahan gula stevia $18 \%$ adalah sampel sari buah pedada yang menghasilkan nilai rata-rata tertinggi yaitu 4,0 dengan kategori suka. Sebanyak 35\% panelis memilih perlakuan A4 ini memberikan respon daya terima terbaik dalam penelitian ini. Berdasarkan komentar yang disampaikan oleh panelis sebagian besar panelis 
menyatakan untuk penerimaan secara keseluruhan sari buah pedada memiliki warna agak oranye untuk sampel yang diberikan gula sukrosa sedangkan sampel yang diberikan dan tanpa diberikan gula stevia bewarna jernih, tekstur secara keseluruhan adalah cair, aroma secara keseluruhan seperti aroma khas buah pedada, dan rasa minuman sari buah pedada secara keseluruhan manis perpaduan asam, kecuali sampel A2 yang murni tanpa penambahan gula rasa yang dinilai sangat asam. Panelis lebih menyukai sampel minuman sari buah pedada perlakuan A4 yaitu penambahan gula stevia $18 \%$ jika dibandingkan dengan sampel lain dengan alasan bahwa sampel A4 karena rasanya yang asam mendekati manis.

\section{KESIMPULAN}

Daya terima minuman sari buah pedada dengan penambahan gula stevia perlakuan yang paling disukai adalah perlakuan A4 (18\% gula stevia) dengan skor warna 3,9 (agak suka), aroma 3,9 (agak suka), tekstur 4,0 (suka), rasa 4,0 (suka), dan overall 4,0 (suka).

Pembuatan minuman sari buah pedada dengan penambahan gula stevia dapat diaplikasikan kepada masyarakat dan dikembangkan menjadi sebuah produk pangan minuman agar sari buah pedada dapat lebih dikenal masyarakat serta dapat menjadi produk olahan pangan fungsional.

\section{UCAPAN TERIMA KASIH}

Ucapan terima kasih disampaikan kepada semua pihak yang telah berperan dalam penyusunan dan pelaksanaan penelitian mengenai "Gambaran Daya Terima Minuman Sari Buah Pedada (Sonneratia sp.) Dengan Penambahan Gula Stevia (Stevia Rebaudiana)" di Kota Jambi, sehingga inovasi baru pengolahan minuman sari buah pedada dengan penambahan gula stevia dapat diterima oleh masyarakat dan dapat dituangkan dalam bentuk tulisan.

\section{DAFTAR PUSTAKA}

Ahmed, R., J. Moustami, H. Ahmed, M. Ali, R. Haq, and Rahmatullah. 2010. Serum glucose and lipid profiles in rats following administration of Sonneratia caseolaris (L.) Engl. (Sonneratiaceae) leaf powder in diet.
Advance in Natural and Applied Science 4: 171-173.

Alizadeh, M., A. Maryam, H. Helaleh, and K. Sorayya. 2014. Effect of stevia as a substitute for sugar on physicochemical and sensory properties of fruit based milk shake. Journal of Scientific Research \& Reports 3: 1421-1429. DOI: 10.9734/JSRR/2014/8623.

Amalia, F. 2016. Pengaruh Grade Teh Hijau dan Konsentrasi Gula Stevia (Stevia rebaudiana bertoni M.) Terhadap Karakteristik Sirup Teh Hijau (Green Tea). Skripsi. Universitas Pasundan, Bandung.

Amriani, H., S. Husain, and W. Mohammad. 2019. Pembuatan teh fungsional berbahan dasar buah mahkota dewa (Phaleria macrocarpa) dengan penambahan daun stevia. Jurnal Pendidikan Teknologi Pertanian 5: 251-261. DOI: $10.26858 /$ jptp.v5i0.9085.

Asmawati, H. Sunardi, dan S. Ihromi. 2018. Kajian persentase penambahan gula terhadap komponen mutu sirup buah naga merah. Jurnal Agrotek 5: 97-105. DOI: 10.31764/agrotek.v5i2.700

Balaswamy, K., P.P. Rao, G.N. Rao, A. Nagender, and A. Satyanarayana. 2014. Production of low calorie ready-to-serve fruit beverages using a natural sweetener, stevia (Stevia rebaudiana L.). Journal FMFI 3: 59-65. DOI: $10.14355 /$ fmfi.2014.03.008.

Dari, D.W., dan D. Junita. 2020a. Karakteristik fisik dan sensori minuman sari buah pedada. Jurnal Pengolahan Hasil Perikanan Indonesia 23: 532-541. DOI: 10.17844/jphpi.v23i3.33204.

Dari, D.W., M. Ananda, dan D. Junita. 2020b. Karakteristik kimia sari buah pedada (Sonneratia caseolaris) selama penyimpanan. Jurnal Teknologi Pertanian Andalas 24: 189-195. DOI: 10.25077/jtpa.24.2.189-195.2020.

Dari, D.W., D.T. Ramadani, dan Aisah. 2020c. Kandungan gizi dan aktivitas antioksidan permen jelly buah pedada (Sonneratia caseolaris) dengan penambahan karagenan. Jurnal Akademika Baiturrahim Jambi 9: 154-165. DOI: 10.36565/jab.v9i2.153.

Dari, D.W, L.A Masruroh, dan D. Junita. 2021. Karakteristik kimia dan derajat keasaman minuman sari buah pedada (Sonneratia sp.) dengan penambahan natrium benzoat. Jurnal Teknologi Pangan dan Gizi 20: 35-44. 
Desrosier, N.W. 2008. Teknologi Pengawetan Pangan. Terjemahan M. Muljohardjo. UIPress. Jakarta.

Fitri, E., N. Harun, dan V.S. Johan. 2017. Konsentrasi gula dan sari buah terhadap kualitas sirup belimbing wuluh (Averrhoa blimbi L.). Jurnal JOM Faperta UR. 4: 1-13.

Ghazi, I., B. Wicaksono, dan Abdullah. 2013. Penghilangan warna coklat larutan gula stevia menggunakan karbon aktif. Jurnal Teknologi Kimia dan Industri 2: 198-204.

Junita, D., B. Setiawan, F. Anwar, dan T. Muhandri. 2017. Komponen gizi, aktivitas antioksidan dan karakteristik sensori bubuk fungsional labu kuning (Cucurbita moschata) dan tempe. Jurnal Gizi dan Pangan 12: 109-116. DOI: 10.25182/jgp.2017.12.2.109-116.

Meilina, M. 2019. Karakteristik Fisik dan Sensori Minuman Sari Buah Pedada (Sonneratia caseolaris). Skripsi. STIKes Baiturrahim, Jambi.

Manalu, R.D.E. 2011. Kadar Beberapa Vitamin Pada Buah Pedada (Sonneratia caseolaris) dan Hasil Olahannya. Skripsi. IPB, Bogor.

Novriyanti, S. Wahyuni dan M. Syukri. 2016. Analisis penilaian organoleptik cake brownies subtitusi tepung wikau maombo. Jurnal Sains dan Teknologi Pangan 1: 5866.

Parpinello, G.P., A. Versari, M. Castellari, and S. Galassi. 2001. Stevioside as a replacement of sucrose in peach juice: Sensory evaluation. Journal of Sensory Studies 16: 471-484. DOI: $10.1111 / \mathrm{j} .1745$ 459X.2001.tb00314.x.

Rahman, R., U. Pato, dan N. Harun. 2016. Pemanfaatan buah pedada (Sonneratia caseolaris) dan buah naga merah (Hylocereus polyrhizus) dalam pembuatan fruit leather. Jurnal JOM Fapeta 3: 1-15.

Raini, M., dan A. Isnawati. 2011. Kajian: Khasiat dan keamanan stevia sebagai pemanis pengganti gula. Media Litbang Kesehatan 21: 145-156.

Rajis, Desmelati, dan T. Leksono. 2017. Pemanfaatan buah mangrove pedada (Sonneratia caseolaris) sebagai pembuatan sirup terhadap penerimaan konsumen. Jurnal Perikanan dan Kelautan 22: 51-60.

Ramadani, D.T., D.W. Dari, dan Aisah. 2020. Daya terima permen jelly buah pedada (Sonneratia caseolaris) dengan penambahan karagenan. Jurnal Akademika Baiturrahim Jambi 9: 15-24. DOI: 10.36565/jab.v9i1.151

Ramadani, D.T., M. Meilina, Y. Arsita, D.W. Dari, dan N. Safitri. 2019. Pengaruh penambahan gula terhadap karakteristik kimia sirup pedada (Sonneratia caseolaris). Prosiding Seminar Nasional Gizi 1 (STIKes Baiturrahim Jambi). Hal. 44-50.

Rahmadhani, S., D.W. Dari, dan D. Junita. 2021. Gambaran karakteristik kimia minuman sari buah pedada (Sonneratia sp.) dengan penambahan gula stevia. Jurnal Sains dan Teknologi Pangan 6: 3731-3744.

Ratnani, D., dan R. Anggraeni. 2005. Ekstraksi gula stevia dari tanaman stevia Rebaudiana bertoni. Momentum 1: 27-32.

Rocha, I.F.d.O. and H.M.A. Bolini. 2015. Passion fruit juice with different sweeteners: Sensory profile by descriptive analysis and acceptance. Food Science \& Nutrition Journal 3: 129-139. DOI: 10.1002/fsn3.195.

Rukmana, R. 2003. Budi Daya Stevia Bahan Pembuatan Pemanis Alami. Yogyakarta: Penerbit Kanisius.

Sumantri, M. 2018. Daya Terima Sirup Buah Pedada (Sonneratia caseolaris) Berdasarkan Perbedaan Konsentrasi Gula. Skripsi. STIKes Baiturrahim, Jambi.

Susanty, A., dan E. Sampepana. 2017. Pengaruh masa simpan buah terhadap kualitas sari buah naga merah (Hylocereus polyrhizus). Jurnal Riset Teknologi Industri 11: 76-82.

Sylvetsky, A.C., and K.I. Rother. 2016. Trends in the consumption of low-calorie sweeteners. Physiology \& Behaviour 164(Pt B): 446450. DOI: 10.1016/j.physbeh.2016.03.030.

Tahir, M., B. Mariyati, dan Nurmitasari. 2017. Pembuatan Minuman Seduh Daun Kersen (Muntigia Calabura. L) dengan Penambahan Daun Stevia (Stevia rebaudiana) Sebagai Pemanis Alami Rendah Kalori. Dalam: Prosiding Seminar Nasional FKPT-TPI 2017. Sulawesi Tenggara, 20-21 September 2017.

Wahyuningtias, D. 2010. Uji organoleptik hasil jadi kue menggunakan bahan non instant dan instant. Binus Business Review 1: 166125. DOI: 10.21512/bbr.v1i1.1060.

Widad, N., Nazaruddin, dan H. Dody. 2018. Pengaruh Konsentrasi Gula Stevia Terhadap Vitamin C dan Sensoris Minuman Kombucha Sari Buah Nanas. Artikel Ilmiah. Universitas Mataram, Mataram. 
Winarno, F.G. 2004. Kimia Pangan dan Gizi. Jakarta: Gramedia Pustaka Utama: 253 halaman.

Wiratno, S.A., V.S. Johan, dan F. Hamzah. 2017. Pemanfaatan buah pedada (Sonneratia caseolaris) dalam pembuatan minuman instan. JOM Faperta UR 4: 1-13.

Zaitoun, M., M. Ghanem, and S. Harphoush. 2018. Sugars: Types and their functional properties in food and human health. International Journal of Public Health Research 6: 93-99. 